\title{
Assessment of Major Bridges Along Nasarawa, Plateau, Bauchi and Gombe State Highway, Northern Central, Nigeria
}

\author{
Mlanga Victor Musa Kyauta Ekpo Ekpeyong Alhassan Iko David \\ Nigerian Building \& Road Research Institute, 10 NBRRI Road/ I.T. Igbani Street, Jabi District, Abuja, FCT, \\ Nigeria
}

\begin{abstract}
Nigerian road infrastructure is in a despicable condition most especially the culverts and the bridges across the Country and majority of the bridges constructed on Nigerian highways are girder bridges. Most of the infrastructure are decaying, overstretched and aged, all attributed to poor maintenance of the transport infrastructure. Bridges are essential components of national growth which enables the movement of goods and services across inter-states, regions and beyond national boundaries. The current structural integrity of these girder bridges is either not documented or documentation is unavailable to the general public. This research looked at the current status of girder bridges along the Keffi/Uke - Gombe highway with the objective of building a database on the structural status of the existing bridges and its components. The inspection team documented and graded any concerns and proffered solutions to guide the authorities in deciding repair and rehabilitation requirements where deemed necessary. Visual Inspection Method (VIM) and the use of Unmanned Aerial Vehicle (UAV) were the methods used for data collection on the condition of bridges along the route. The data from the inspection carried out indicated the absence of any kind of maintenance, repair or rehabilitation by qualified professionals on most of the existing bridges along the route. However, it was observed that the Dindima and Gwaram Bridges need immediate preventive rehabilitation while the Kwadon / Liji /Kurba Bridge has failed due to poor design and should be reconstructed.
\end{abstract}

Keywords: Girder bridge, Visual inspection, Transport infrastructure, Highway maintenance

DOI: $10.7176 /$ CER/11-8-02

Publication date:September $30^{\text {th }} 2019$

\subsection{INTRODUCTION}

Bridges are a critical component of a nation's infrastructure, making it possible to transport raw materials and finished goods to factories, warehouses, suppliers, distributors, stores, and end-consumers. Bridges also facilitate travel so consumers can purchase goods and services in their own communities and beyond. When a bridge becomes inaccessible, economic activity slows or grinds to a complete halt (Bridge Masters, 2017).

Girder Bridges are the oldest form of bridges. This is probably due to their simplicity as in its most basic form; a girder bridge consists of a horizontal beam resting directly on supports at each end. As the name implies, these bridges receive traffic loads from the deck directly to girders placed longitudinally to the direction of traffic, or transversely and in turn supported by main beams as the case may be. These girders endure compressional forces at the top and tensional forces at the bottom. The longer the span gets, the weaker the bridge becomes. Hence the need for girder bridges to have several spans where necessary (R.K. Bharil, 2016).

Girder bridges are mostly made from concrete, steel, or a combination of both materials to handle the selfweight and live loads being transmitted from the deck down through to the piles in the ground. The size of the girder, and in particular the height of the girder, controls the distance that the girder can span. By increasing the height, the girder has more material to dissipate the tension. To create very tall girders, bridge designers add supporting latticework, or a truss, to the bridge's girder. This support truss adds rigidity to the existing girder, greatly increasing its ability to dissipate the compression and tension. Once the girder begins to compress, the force spreads through the truss (Lamb et al, 2000).

\subsection{POTENTIALS OF STATES AlONG THE NASARAWA - PlateAU - BAUCHI - GoMbe HIGHWAY}

The Nasarawa (Uke) - Gombe highway is an approximately 555kilometres long federal road (Agbakwuru, 2018). It is the major route integrating the north central part of Nigeria with the south east and the north eastern part of the country. It provides access for the movement of agro produce, goods and services between these regions. The highway runs across four states in northern Nigeria namely; Nasarawa, Plateau, Bauchi and Gombe States. Nasarawa State is a major producer of cash crops like groundnut, yam, grains and potatoes; but it is known majorly for its tourist sites like Farin Ruwa Falls, and the Salt Village in Keana Local Government Area of the state. Plateau State is the most important mining area in Nigeria; its major exports being tin and columbite (Wapwera et al, 2015). Besides the popular Yankari Game Reserve being located in Bauchi State, the state is also known for agriculture and its mining products. The people of Gombe State are primarily farmers producing food and cash crops. Fig: 1. 


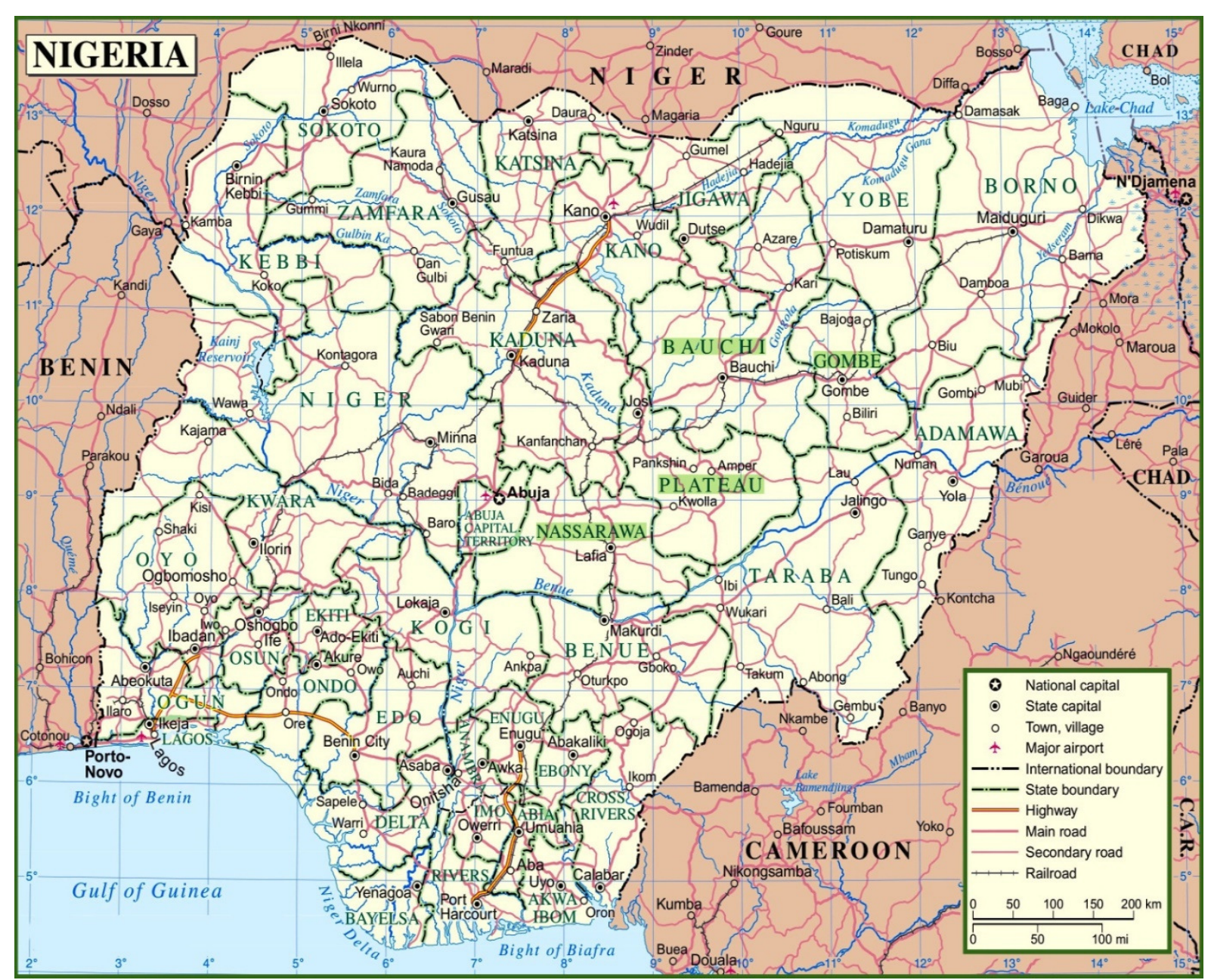

Figure 1: MAP OF NIGERIA SHOWING STATE BOUNDARIES AND ROADS

\subsection{BRIDGE INSPECTION}

Bridges are costly, crucial and valuable transportation assets on roads. They are a key part of our transportation system, and maintaining this infrastructure is important to ensure the safety of the traveling public as well as to maximize the useful life of these valuable assets. The most important objective of a safety bridge inspection is to verify the structural integrity of the bridge. Information gathered during bridge inspections is used by engineers to plan for maintenance and rehabilitation of the bridges in order to reach or even extend their intended life span, or in a worst case scenario; the replacement of these bridges (Barritt, L et al, 2018). Bridge inspection is a major tool in financial prudence for any well-meaning road authority as the construction of these often large structures is very capital intensive. Hence the need for early detection of critical structural defects in order to protect, maintain and retain safety standards for general traffic along the already existing bridges in the country.

American Association of State Highway Transportation Officials classifies bridge inspections into eight types, namely: Initial, Routine, Damage, In-depth, Fracture-critical, Underwater, Routine wading, and Special inspections. The routine inspection is primarily done as a visual inspection to detect any immediate concerns on the bridge components. Further investigating and non-destructive tests may be carried out if the results of the visual inspection advices further investigation (Gillins, 2011).

\subsubsection{Visual Inspection Method (VIM) for Bridge Inspection}

Visual inspection techniques are the primary methods used to thoroughly and carefully evaluate the condition of the majority of the world's highway bridges (Graybeal, B.A et al, 2002). The VIM is a highly subjective, nondestructive evaluation of components of a bridge. It entails inspecting bridge superstructures and substructures for wear, damage and deterioration with the naked eye to detect cracks, spalling, extruding elastomers, leaking joints, deformations, etc. It is a straightforward approach which does not require tedious training. Inspected components are then rated according to the requirements of the Department of Transportation (DOT) bridge inspection manual. This method does not provide an assessment of the interior of a bridge component, and only analyzes issues in need of immediate repair. Hence to further investigate the internal state of a bridge component, specialized equipment is needed. 


\subsubsection{Unmanned Aerial Vehicle (UAV)}

Considering that bridges are always erected over gorges or rivers, the safety of bridge inspectors has always been an issue; especially when it gets to the structural components below the deck. The usual methods of using ladder, scaffolds, aerial work platforms or an Inspecting Vehicle is not only expensive and risky, but also very time consuming and tedious. Besides an Under Bridge Inspection Truck (UBIT)being expensive to rent and maintain, its use requires traffic control which results in travel time delays.

An Unmanned Aerial Vehicle (UAV), commonly known as a drone is an aircraft which does not require a pilot on board to fly it. The drone is piloted by a remote control in the hands of a trained controller. In modern day bridge inspection, powerful cameras are attached to drones in order to collect high-definition images and visual data from usually hard-to-access areas like girders, bearings and the deck soffit. They can be further equipped with thermal cameras, so as to provide additional information on condition of reinforced concrete and steel components (Duque, 2017). Drone-aided inspection often does not affect traffic flow as a thorough inspection can be executed without shutting down the whole bridge or any lanes during the duration of the work (REDNOA Inc., 2017).

AASHTO did a survey in March, 2016 in which they got the price and labour for performing bridge inspections manually and then also got the valuation for carrying out the same duties with a UAV-assisted inspection. These valuations were then compared and it was discovered that not only did the UAV-assisted inspection require just half the number of people used for the manual inspection; it also cost 18.4 times less than the manual bridge inspection. Thus it is clear to see the advantage of UAVs in modern day bridge inspection in terms of safety, cost, duration and efficiency.

\subsection{BRIDGE MAINTENANCE, REHABILITATION AND SERVICEABILITY EXPECTATIONS}

The repair of bridges often has been a reactive activity, initiated only when deterioration threatens the safety or tolerance of the public. Bridge preservation tactics are actions or strategies that prevent, delay, or reduce the deterioration of bridges or sections of them. They return bridges to working order, keep them in good condition, and extend their lives. Preservation activities may be done to prevent deterioration or to correct existing conditions. Preservation is more reactive than proactive. However, maintaining and rehabilitating bridges while they're in relatively good condition and before the onset of serious deterioration can delay the need for costly bridge reconstruction or replacement (Bridge Masters, 2017).

\subsection{METHODOLOGY}

Team of engineers set out from Abuja and travelled along the stated route to Gombe State. A stop was made at every girder bridge along the way and the length of each bridge was taken with a surveyor's wheel. This inspection exercise focused only on bridges 100 metres or longer in length, with the exception of Gwaram Bridge and Kwadon / Liji /Kurba Bridge which were given special consideration. The engineers split into teams of two for the exercise. While walking the deck, one person carried out the inspection while the other had the duty of a safety monitor. As a necessary precaution, the teams of two ensured to walk the deck facing oncoming traffic. The team went along and under each bridge and conducted a physical assessment with aid of the following tools:-

1. DJI Phantom 3 Sport Edition Drone

2. Bridge Inspection Field Manual Version 2.0 MDOT (2016)

3. Geospatial Positioning System (GPS) Receivers

4. Digital Cameras

5. Surveyors Wheel

6. Measuring Tapes

7. Federal road maps of Abuja, Nasarawa, Plateau, Bauchi and Gombe States

8. First Aid Kit

The team of engineers did a thorough UAV aided visual inspection of each girder bridge, taking notes of the condition of the Superstructure Elements: decks, slabs, wearing surface, deck joints, railings, approaches, girders, bearings and finally the Substructure Elements: abutments, piers, pier caps, pier walls, and footings. The UAV was flown along the sides and underneath the girder bridge decks in order to capture high definition images of the soffit of the decks and also the deck fascia. It was mainly used to obtain images and videos of structural components of the bridge substructure normally hard to access and assess by manual inspection. These high definition images were for further study and perusal by the team of engineers.

For each bridge, all the components were carefully inspected and rated by the Bridge Inspection Field Manual criterial. It should be acknowledged here that opinion differed on some of the ratings and had to be resolved by debate before concluding. 
3.0 RESULTS AND DISCUSSION

TABLE 1A. CHARACTERISTICS OF THE INSPECTED GIRDER BRIDGES

\begin{tabular}{|c|c|c|c|}
\hline & Bridge & Bridge & Bridge \\
Variable List & $\mathbf{1}$ & $\mathbf{2}$ & Gwanje \\
\hline Area Located & Uke & Hadari & Nasarawa \\
\hline State Located & Nasarawa & Nasarawa & $\mathrm{N}^{\circ} 54.796^{\prime}$ \\
\hline GPS Location & $\mathrm{N}^{\circ} 8^{\circ} 54.742^{\prime}$ & $\mathrm{N} 08^{\circ} 50.113^{\prime}$ & $17.216^{\prime}$ \\
& $\mathrm{E} 07^{\circ} 42.803^{\prime}$ & $\mathrm{E} 07^{\circ} 57.07^{\prime}$ & 120 \\
\hline Structure Length (metres) & 131 & 103 & Concrete Bridge \\
\hline Type of Girder Bridge & Concrete Bridge & Concrete Bridge & Concrete \\
\hline Main Materials & Concrete & Concrete & 5 \\
\hline Number of Spans & 6 & 6 & 4 \\
\hline Number of Girders & 8 & 5 & 2 \\
\hline Number of Lanes & 4 & 2 & \\
\hline
\end{tabular}

Source: Field Survey 2019

TABLE 1B. CHARACTERISTICS OF THE INSPECTED GIRDER BRIDGES

\begin{tabular}{|c|c|c|c|}
\hline Variable List & $\begin{array}{c}\text { Bridge } \\
4\end{array}$ & $\begin{array}{c}\text { Bridge } \\
5\end{array}$ & $\begin{array}{c}\text { Bridge } \\
6\end{array}$ \\
\hline Area Located & Dindima & Gwaram & Kwadon / Liji /Kurba \\
\hline State Located & Bauchi & Bauchi & Gombe \\
\hline GPS Location & $\begin{array}{l}\text { N10 } 14.403^{\prime} \\
\mathrm{E} 10^{\circ} 08.740^{\prime}\end{array}$ & $\begin{array}{l}\text { N10 } 15.755^{\prime} \\
\text { E10 } \\
\end{array}$ & $\begin{array}{ll} & \mathrm{N} 10^{\circ} 16.642^{\prime} \\
\mathrm{E} 11^{\circ} 13.520^{\prime}\end{array}$ \\
\hline Structure Length (metres) & 160 & 65 & 28 \\
\hline Type of Girder Bridge & Composite Bridge & Composite Bridge & Composite Bridge \\
\hline Main Materials & Concrete and Steel & Concrete and Steel & Concrete and Steel \\
\hline Number of Spans & 7 & 5 & 1 \\
\hline Number of Girders & 5 & 5 & 5 \\
\hline
\end{tabular}

Source: Field Survey 2019

\subsection{CONDITION OF UKE BRIDGE}

The Uke Bridge is located along Abuja-Keffi expressway on coordinate N08 $54.742^{\prime}$ E07 ${ }^{\circ} 42.803^{\prime}$ of the prime meridian. They each have 2 lanes. It was observed here that some deck expansion joints are deteriorated and leakage has been observed at the joints and the surrounding concrete. There is major spalling of bituminous wearing course at the adjacent decks near the joints. Also the stone pitching done to the embankments has partly dislodged due to poor concrete mix, allowing vegetation to grow and run off to then erode the slope. Several pile caps have become exposed and are vulnerable to scouring which would lead to exposure of the piles and weaken the pier supports. Concrete spalling 3 inches deep was observed on one of the piers. This has led to rebar exposure and loss of section. The exposed reinforcement bars can be seen to be undergoing corrosion due to the presence of water. Debris was observed to have lodged and settled between the girders on the pier caps due to deck joint leakage. This has encouraged unwanted vegetation growth which can limit longitudinal and lateral movement of the beams and lead to deterioration of the elastomeric bearings. Fig. 2. 


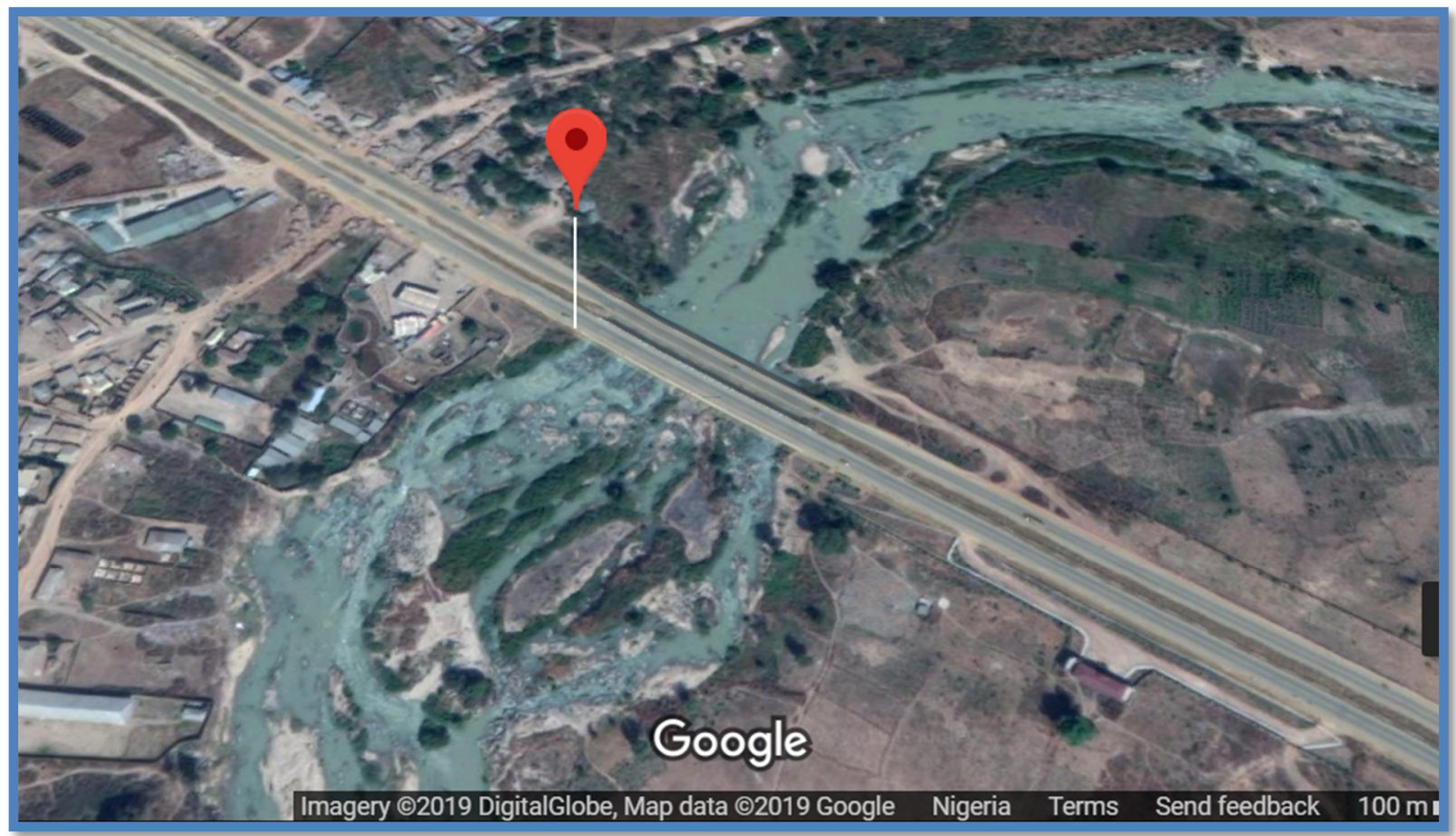

Figure 2. Location map of Uke Bridge along Abuja-Keffi road Source: Google Earth

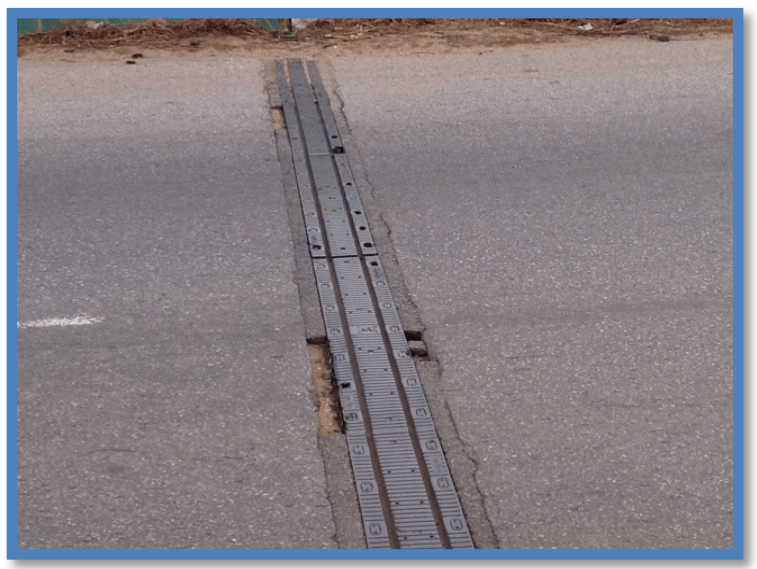

Figure 3a. Deteriorating expansion joint

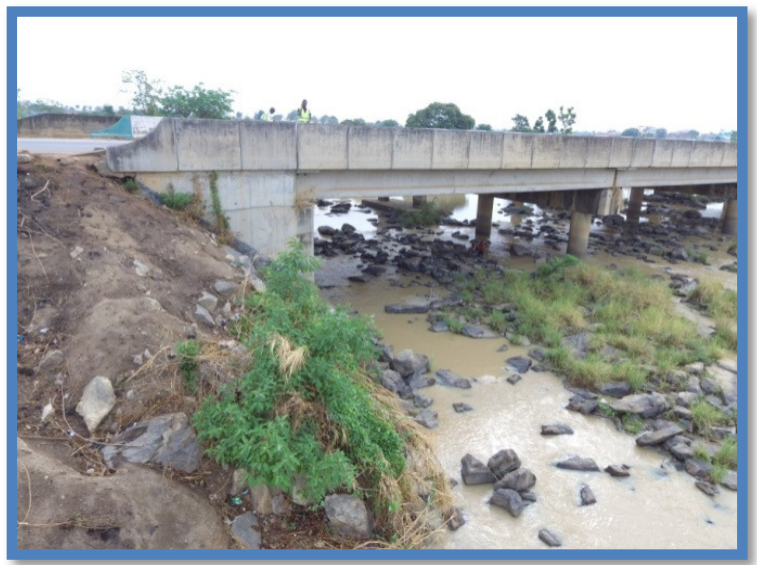

Figure 4.Dislodged stone pitching Source: Field Survey 2019

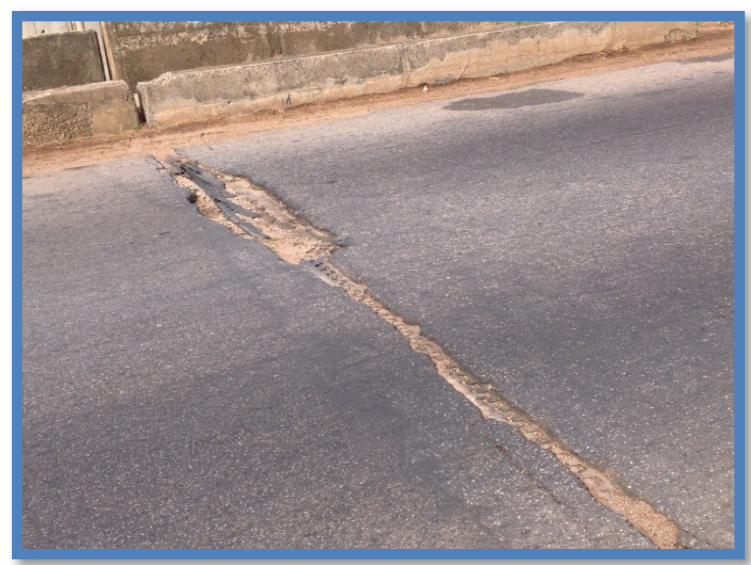

Figure 3b. Deteriorating expansion joint.

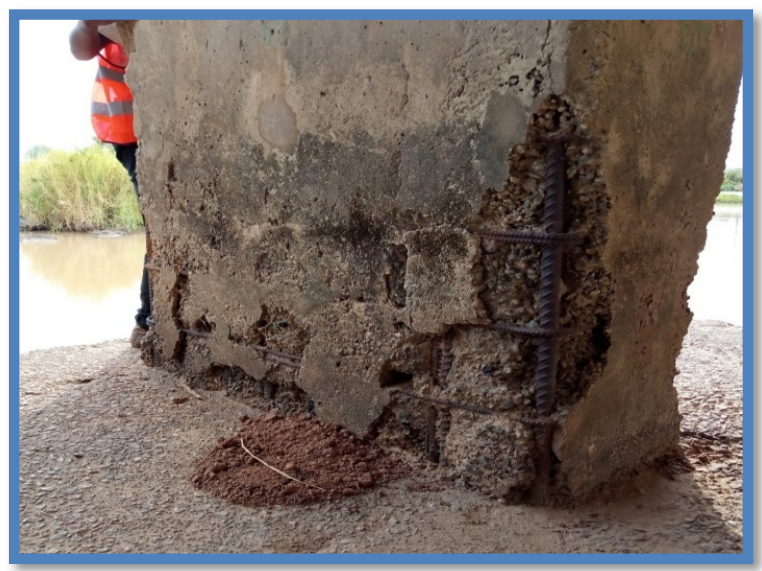

Figure 5.Exposed rebar with section loss 


\subsection{CONDITION OF HADARI BRIDGE}

The stem wall from the Akwanga approach has a pronounced crack starting at its top and proceeding down to the bottom of the abutment. Its wing walls also have noticeable cracks. The team of engineers concluded that the stem wall has insufficient thickness and was poorly designed to withstand the cumulative weight of the backfill, bridge superstructure and traffic load. A tree was also observed to have grown on the bearing seat of the same abutment as shown in figure 7.

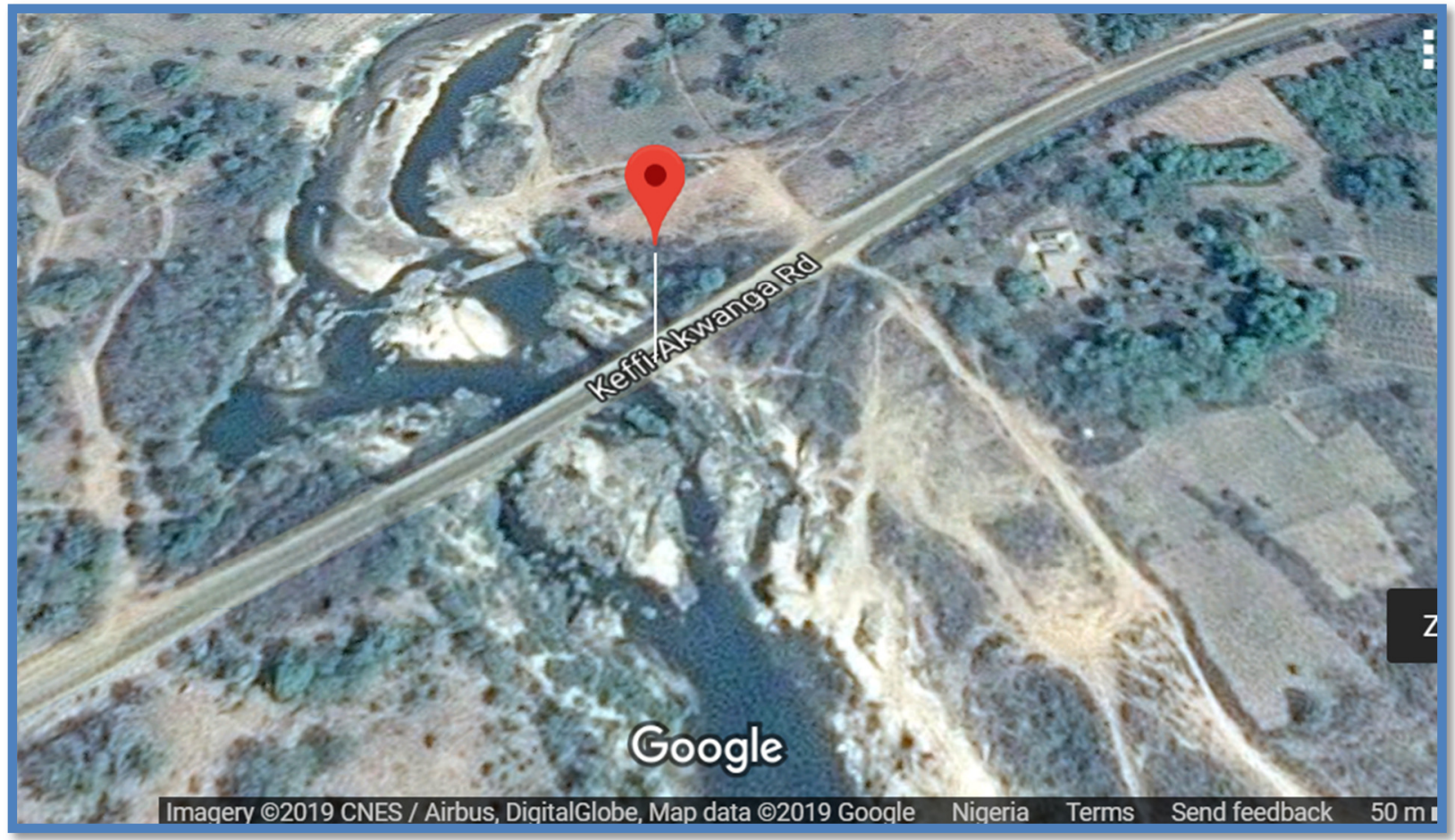

Figure 6. Location map of Hadari Bridge on Keffi-Akwanga road Source: Google Earth

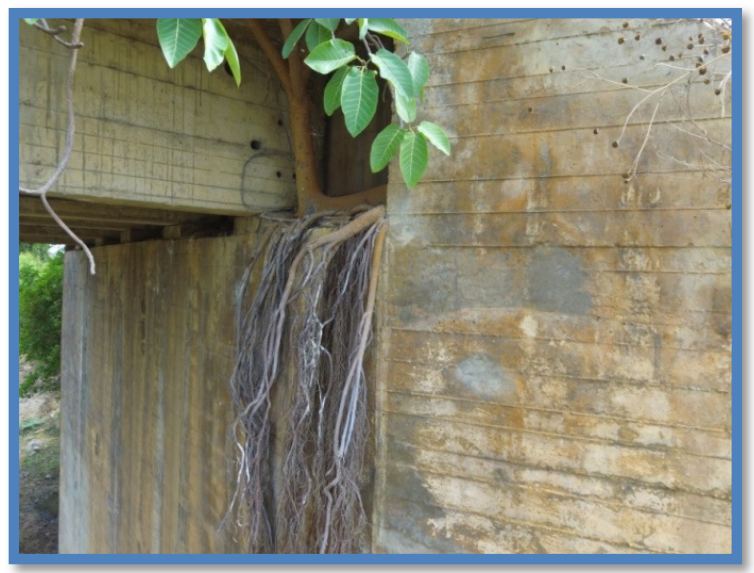

Figure 7.Tree growing on abutment seat.

Source: Field Survey 2019

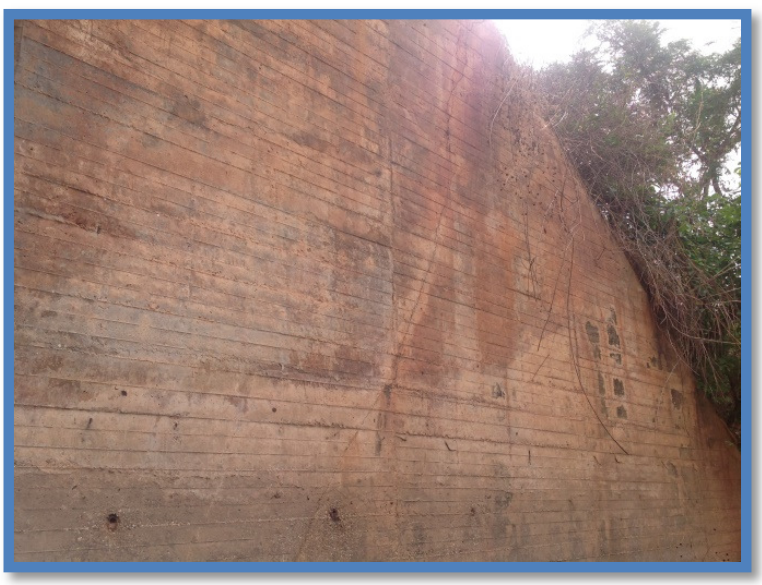

Figure 8.Pronounced crack on wingwall.

The bridge at Hadari also has several of its pile caps exposed by erosion and left vulnerable to scouring. It was observed that some drainage pipes are blocked. This has encouraged vegetation growth on the external sides of the parapet. Debris was observed to have settled between the beams on the pier caps. This has also led to growth of unwanted vegetation on the pier caps.

Lastly, the engineers observed that the embankments of the bridge had been left unprotected without stone pitching or any other erosion-preventive treatment. Thus erosion and landslide due to runoff has removed much of the embankment backfill and trees have grown directly behind the wing wall. 


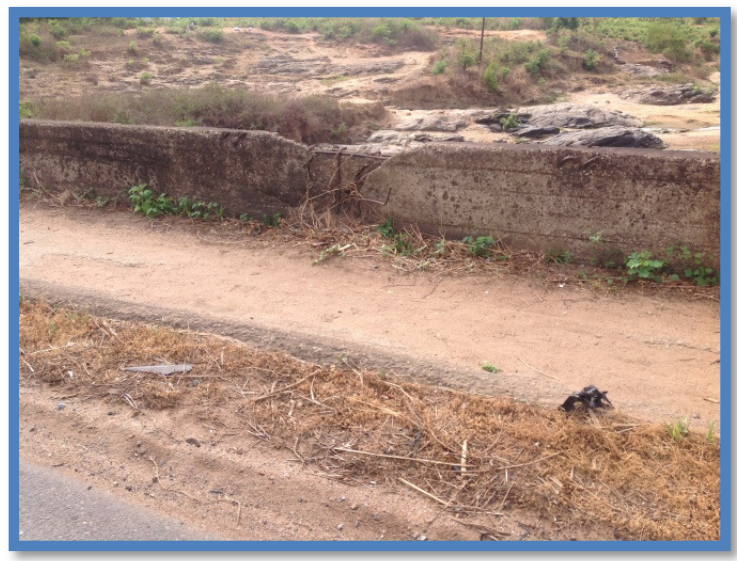

Figure 9.Major spalling of crash barrier Source: Field Survey 2019

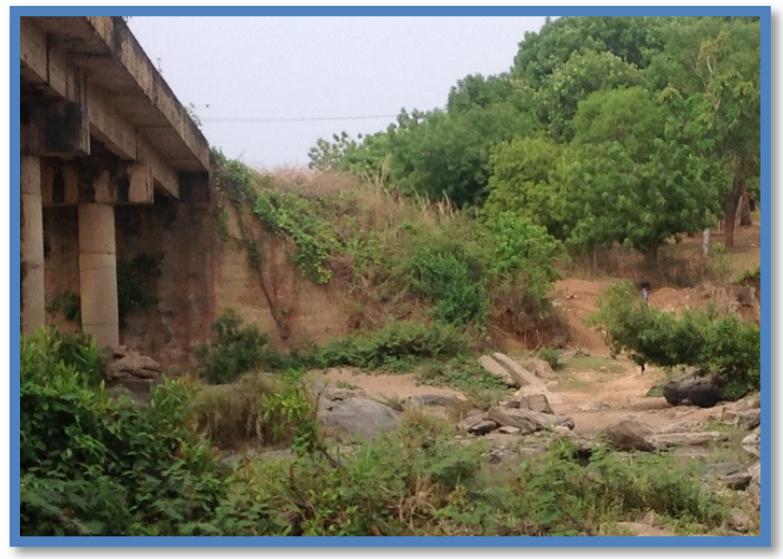

Figure 10.Unwanted vegetation on embankment.

\subsection{CONDITION OF GWANJE BRIDGE}

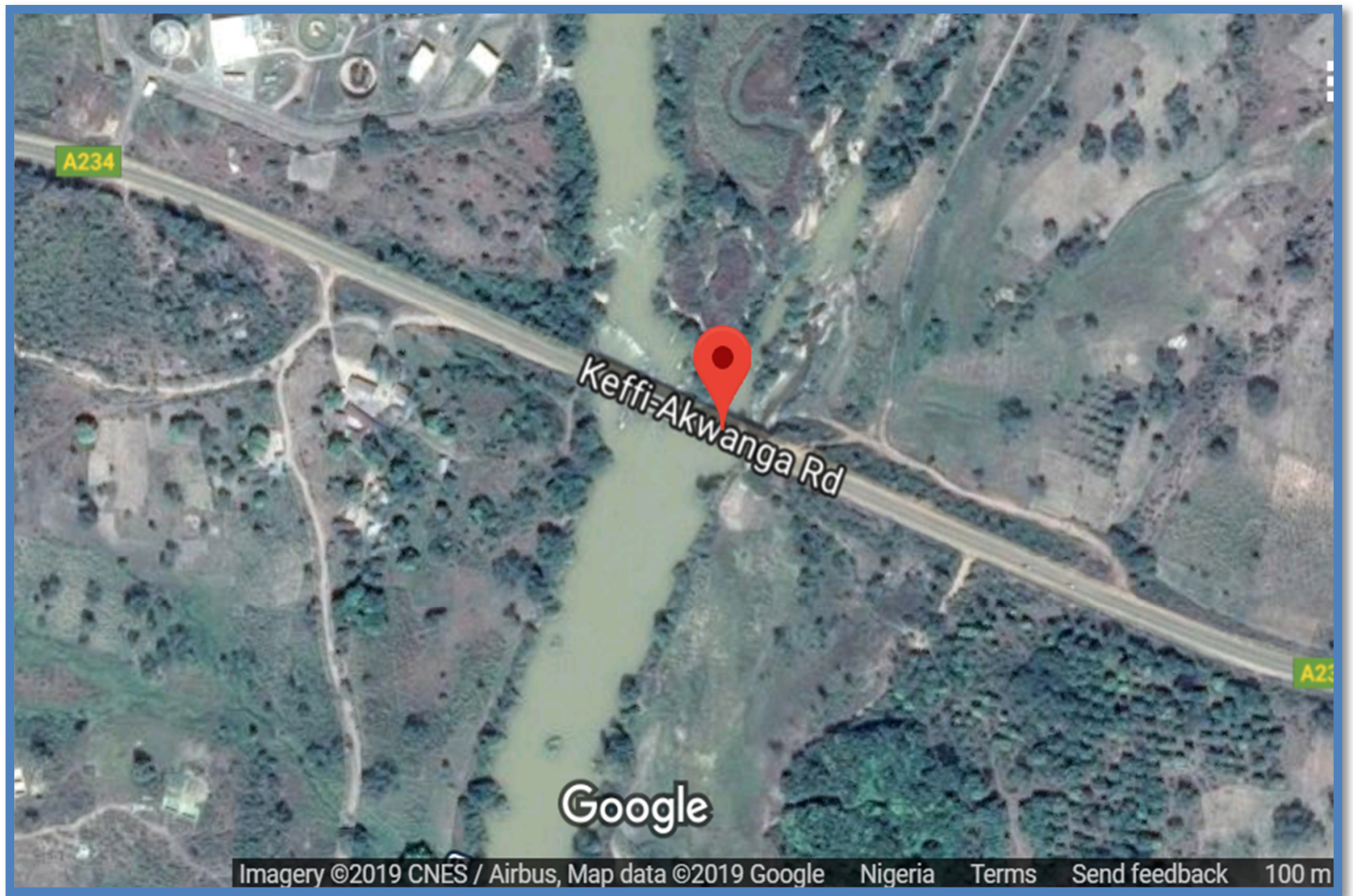

Figure 11.Location map of Gwanje Bridge on Keffi-Akwanga road

Source: Google Earth 2019

The Mada River flows under this bridge. On the bridge deck, major spalling is occurring on the headers adjacent to the expansion joints and debris has infiltrated the joints. Railings are also missing due to vandalism. This bridge has two large trees growing on the bridge fascia. The team of engineers observed that some drainage pipes on the deck are blocked and this has led to water being stagnant on the deck during rainfall. This has encouraged the growth of the trees. 


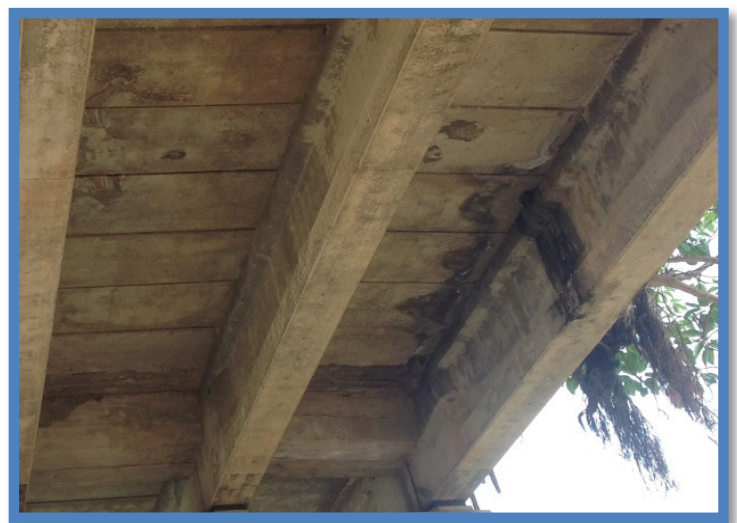

Figure 12.Blocked drain and tree growth.

Source: Field Survey 2019

At some expansion joints under the soffit of the deck and also on the sides of the girders, decaying formwork is noticeably still in places years after the conclusion of the structure. This has led to the debris being lodged in the expansion joints, limiting movement of the bridge. Concrete spalling under the soffit of the deck is noticeable around these areas due to weakening of the concrete by retained water. Cracks $2 \mathrm{~mm}$ wide were observed on some piers below the level normally submerged in water. The team concluded this happened as a result of poor concrete mix during construction of the piers, resulting in thermal cracks to occur. Lastly, some pile caps are also exposed and vulnerable to scouring.
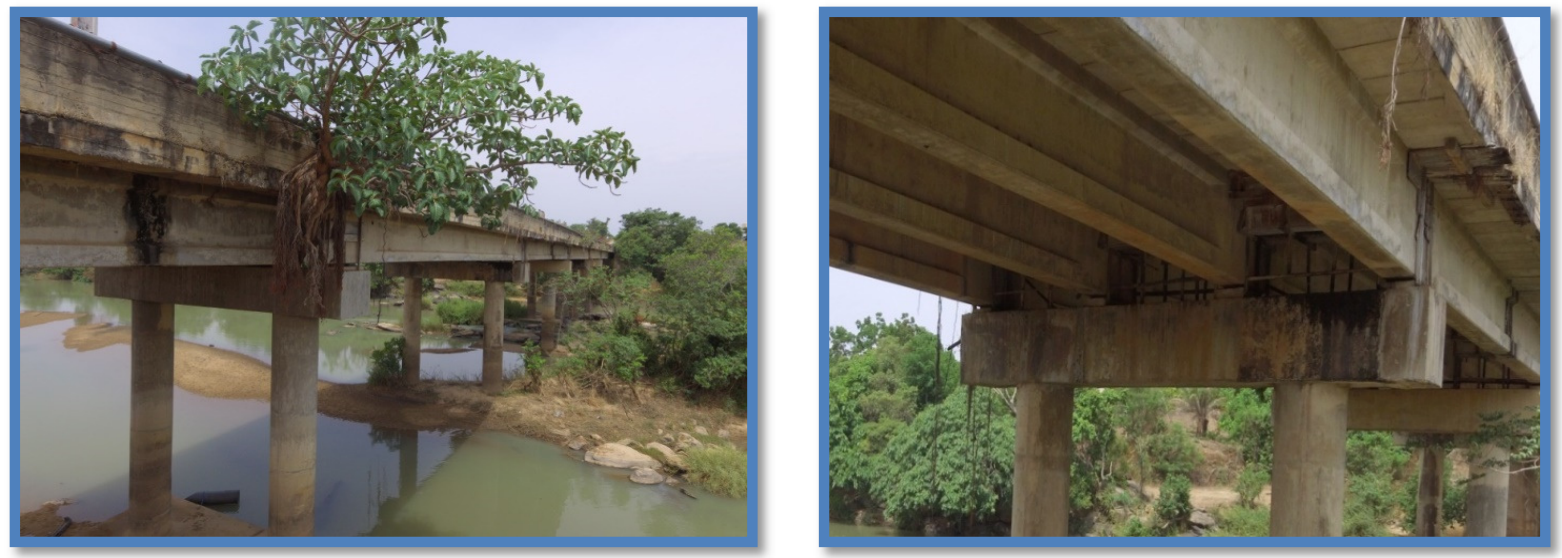

Figure 14.Tree growing on bridge fascia.

Source: Field Survey 2019

\subsection{CONDITION OF DINDIMA BRIDGE}

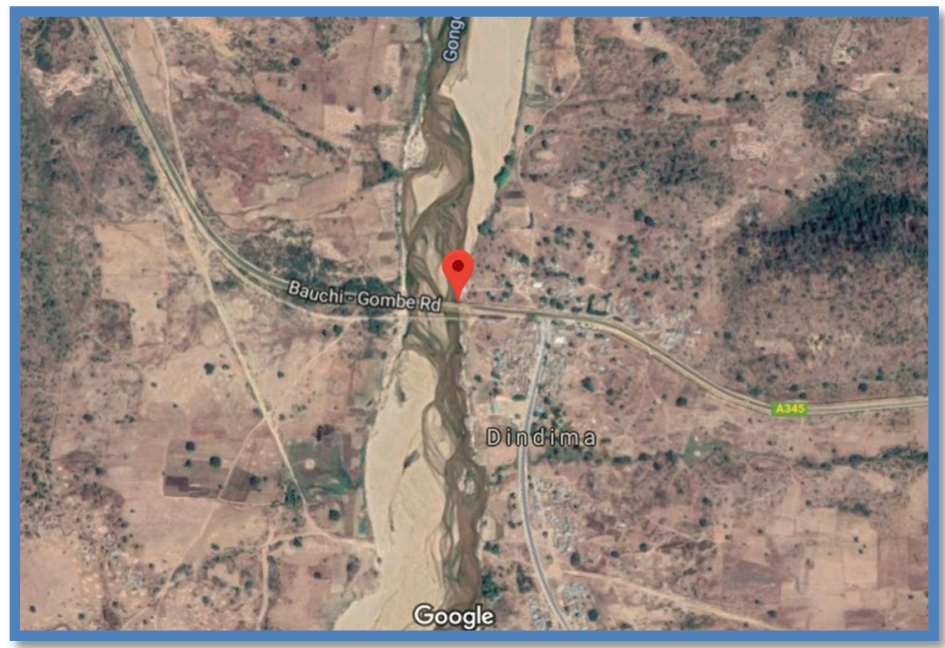

Figure 16.Location map of Dindima Bridge on Bauchi-Gombe road 
The Bridge at Dindima is a composite bridge built with reinforced concrete deck, piers, pier caps, pile caps and abutments, and steel I girders. The Gongola River flows under this bridge. At Dindima the team of engineers noted that the fixed bearings on the approach abutment from Bauchi State have all failed. The elastomers have split and are extruding, bearing alignment and load carrying capacity may be beyond limits and the shear keys have failed. It was also observed that overtime; back fill has been seeping from underneath the bituminous roadway approach through the expansion joint to the bearing seat of the abutment. This has resulted in shear cracks $3 \mathrm{~mm}$ wide on the beam supporting the approach and obvious settlement of the slab. The locals in the area have casted concrete on the bearing seat of the abutment in an attempt to stop further soil loss from the backfill which would cause the bridge to separate entirely from the existing road eventually. Fig. 16
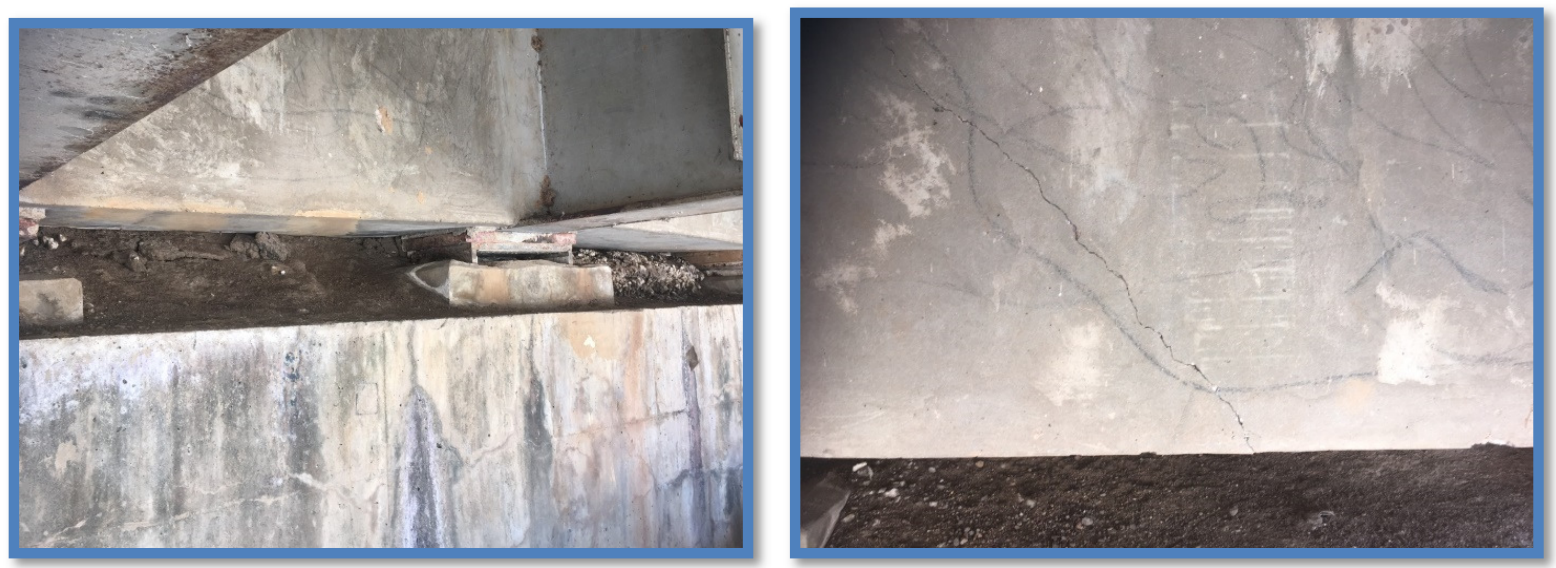

Figure 17.Soil loss from roadway approach.

\section{Source: Field Survey 2019}

Figure 18.3mm wide crack on approach beam

The team also noted that a lot of steel pipe bridge railings were missing, removed by vandals. This has left long distances along the bridge unprotected by any sort of barrier. Shrubs were found to have grown on the bearing seats due to accumulation of debris. It was observed that the channel bed had eroded and this has left some of the pile caps vulnerable to scouring.
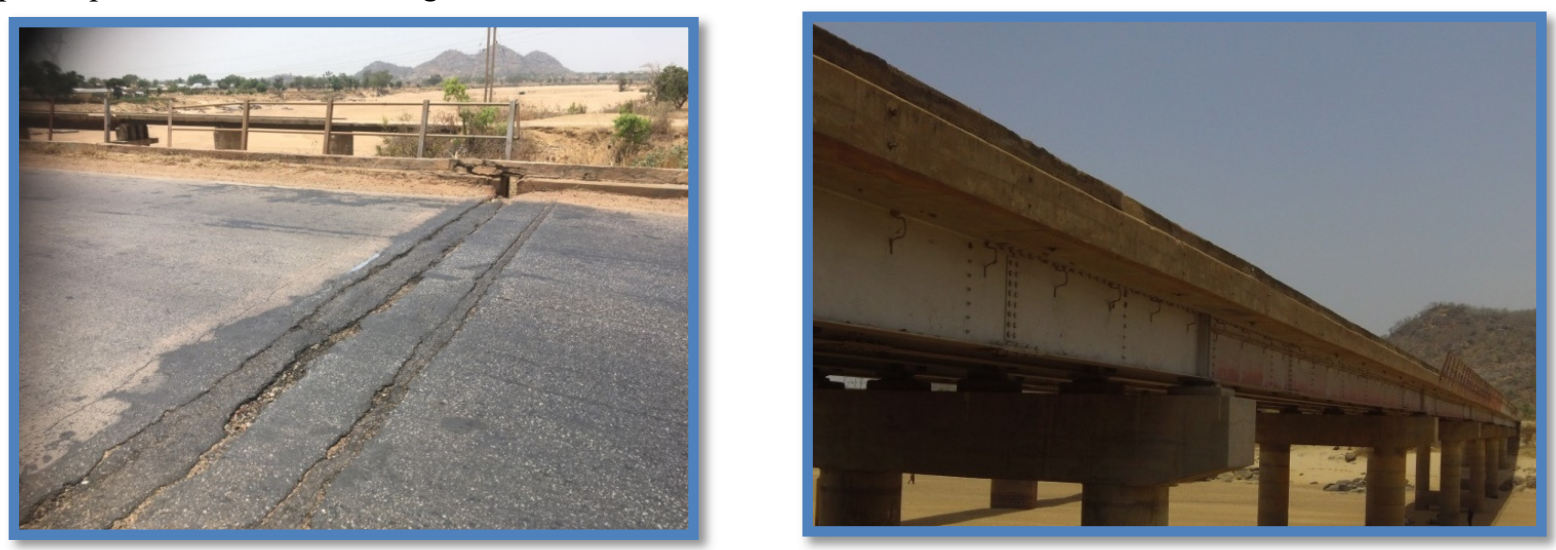

Figure 19.Spalling on approach joint.Figure 20.Missing railings due to vandalism. 


\subsection{CONDITION OF GWARAM BRIDGE}

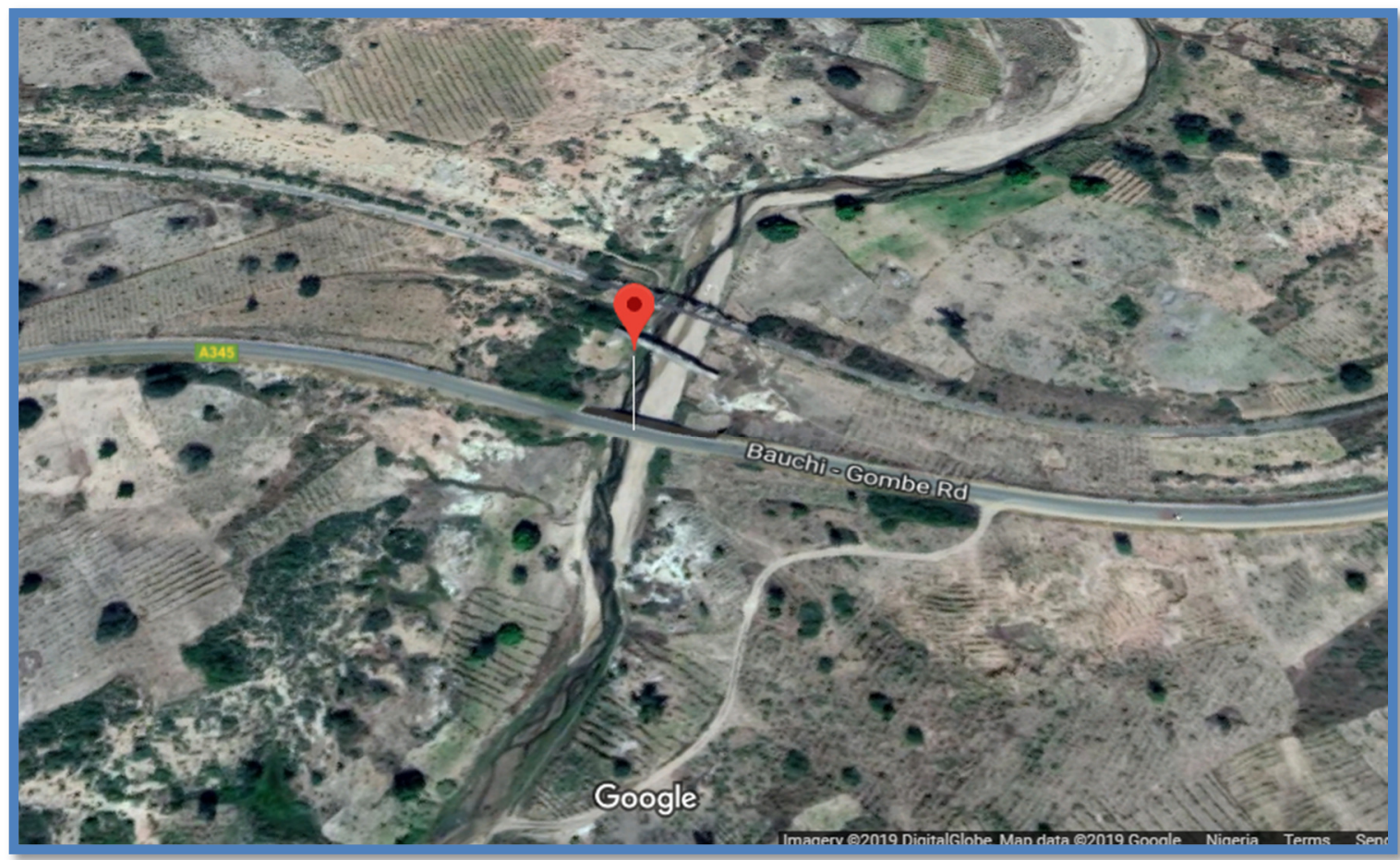

Figure 21.Location map of Gwaram Bridge on Bauchi-Gombe road. Source : Google Earth

The bridge at Gwaram is a composite bridge with the deck, piers, pier caps, pile caps and abutments all made of reinforced concrete while the girders are steel I girders. On this bridge, the team observed that there was barely has any form of protective barriers left. The aluminum bridge railings were all missing either due to impact damage from road accidents or vandalism. This can be a seen in figure 22 .

Further inspection revealed that the channel bed has undergone serious erosion and some pile caps and numerous piles have been left exposed and are undergoing weathering as seen in figure 23 . The team concluded that the piers with exposed piles have reduced support capacity and pose a threat to the structural integrity of the bridge as a whole. This is a potential hazard that could result in loss of lives and property.

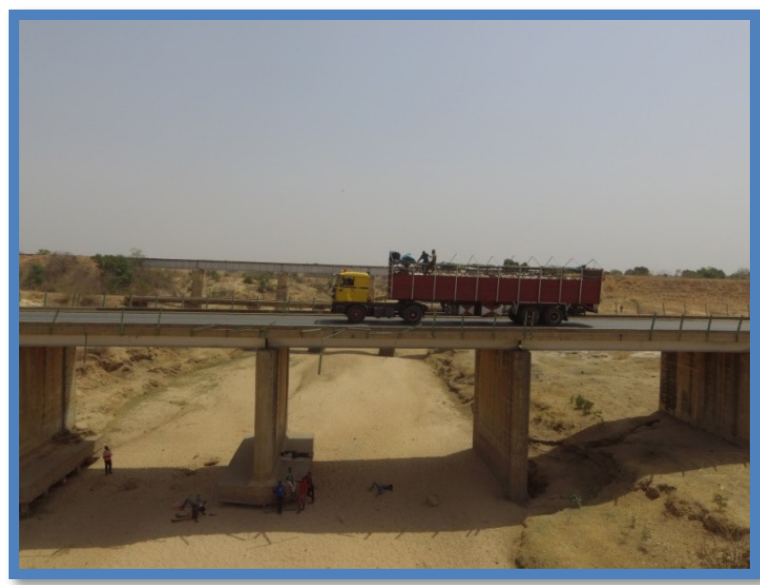

Figure 22.Noticeable absence of railings.

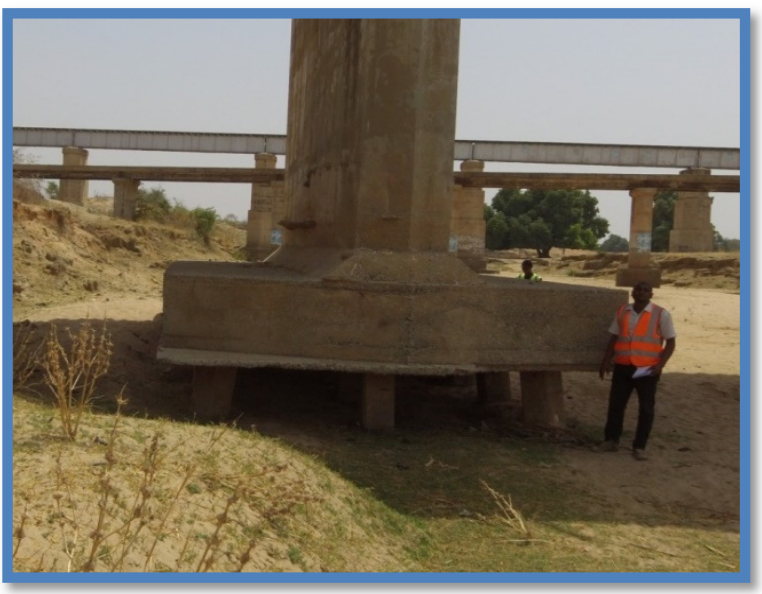

Figure 23.Exposed pile caps and piles 


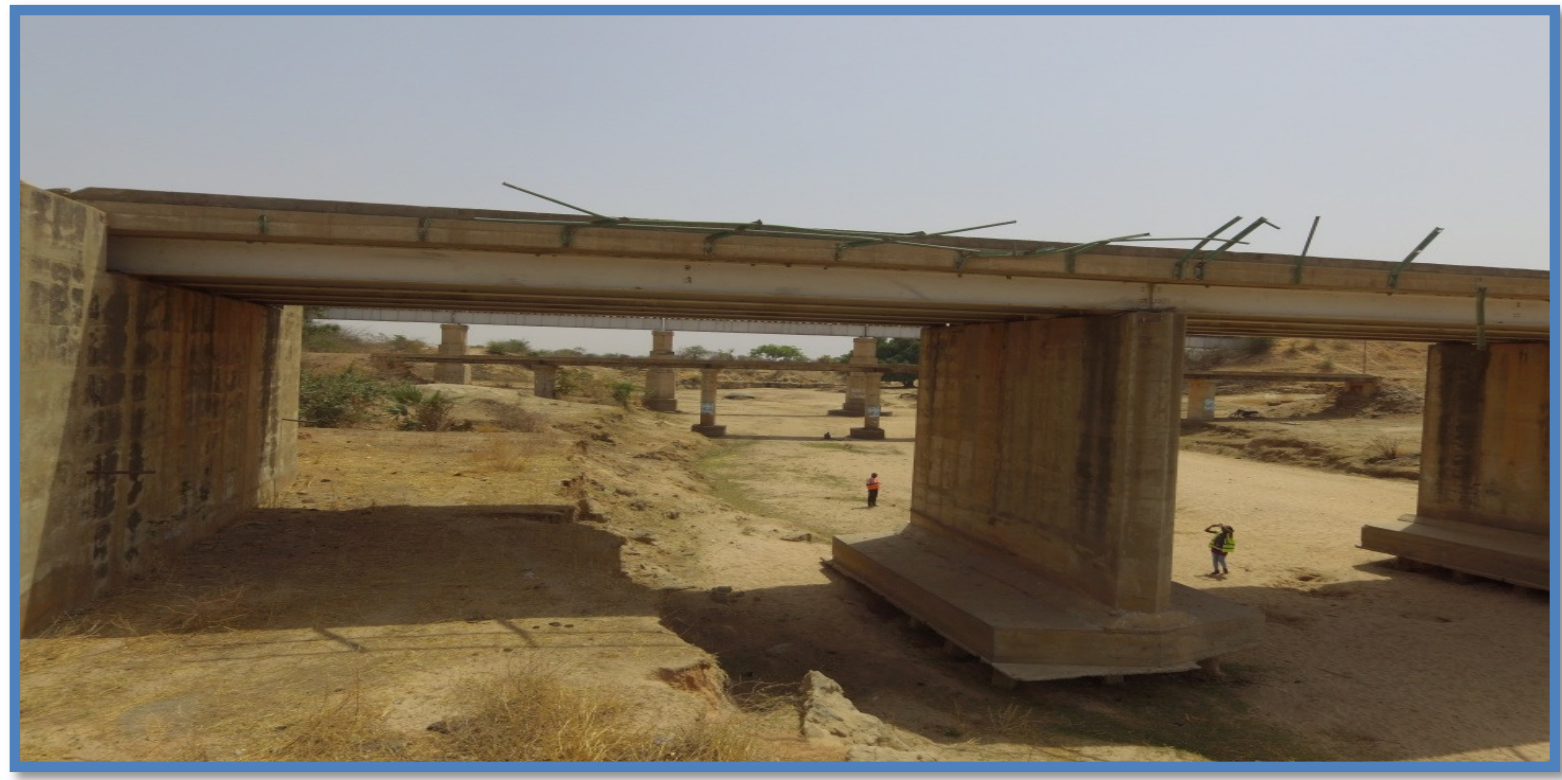

Figure 24.Major loss of channel bed to erosion and scouring. Source: Field Survey 2019

In conclusion, the Gwaram bridge needs immediate preventive maintenance in order to ensure the safety of road users and property along this route and also to preserve and extend the useful life of the bridge.

\subsection{CONDITION OF KWADON / LIJI /KURBA BRIDGE}

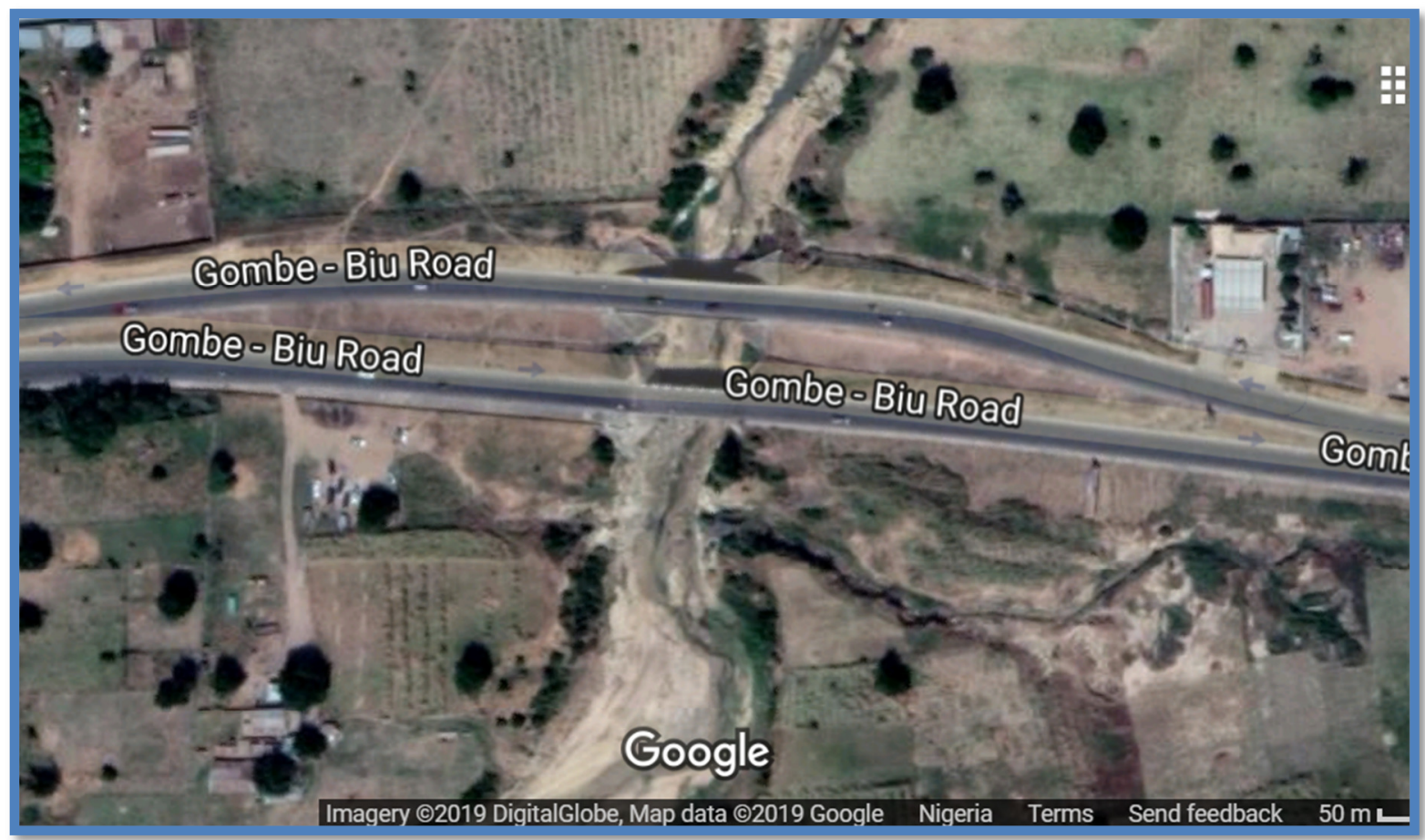

Figure 25.Location map of Kwadon / Liji /Kurba Bridge on Gombe-Biu road

Source: Google Earth 2019

This bridge is located along Gombe-Biu road. The main construction materials are concrete and steel. It has been shut off to general traffic due to its deplorable condition. The abutment from the Gombe approach has literally broken in two directions; horizontally and vertically as seen in figure 26 . The team observed that no reinforcements were used in the construction of the abutment: it was just a big mass of concrete with inadequate tensile resistance to loading. The contractor erroneously designed the abutment to be over 1 metre thick, thinking it sufficient to carry out its functions. This can be seen in figure 27. 


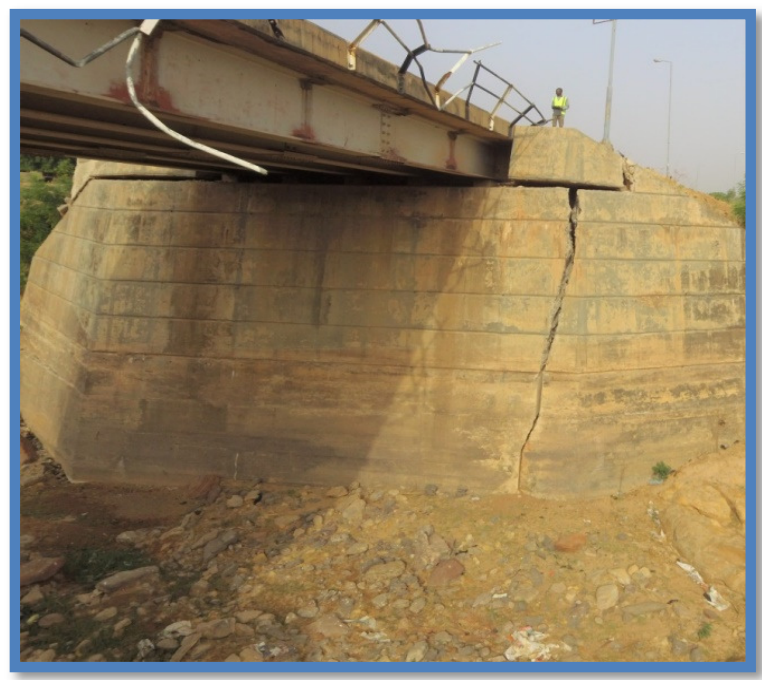

Figure 26. Major cracks on abutment.

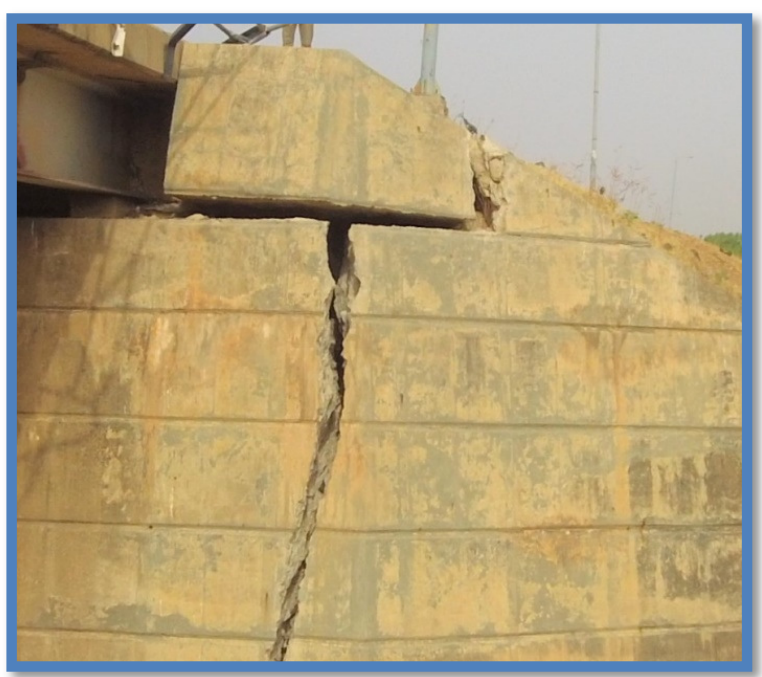

Figure 27.Absence of rebars in abutment.

Also, no form of protection had been applied to the embankment after construction. The soil behind the wing wall has been greatly eroded by water from the highway drainage emptying directly behind the wing wall. This erosion has eaten underneath the approach slab and caused noticeable settlement as one approaches the bridge. In an attempt to stop the backfill erosion, boulders have been dumped behind the wing wall as an afterthought. This action has resulted in further differential settlement of the approach slab.

Lastly, the team of engineers observed that the metal bridge railings along this bridge were either deformed due to impact damage on the bridge, or have been lost to vandalism. This has left the general traffic unprotected by any barriers along the bridge.

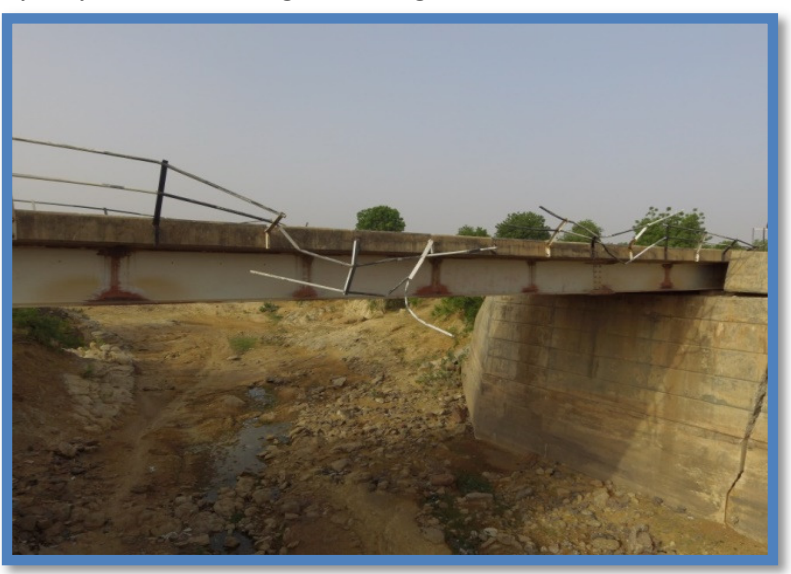

Figure 28. Poor attempt to arrest backfill loss. Source: Field Survey 2019

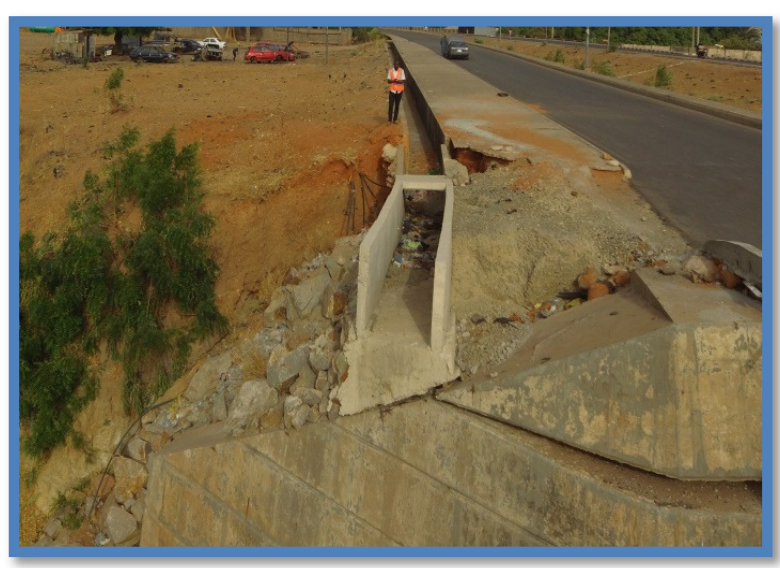

Figure 29.Deformed guardrails.

\subsection{CONCLUSION AND RECOMMENDATIONS}

The revealed that the majority of bridges along the Nasarawa, Plateau, Bauchi and Gombe State Federal Highway are in terrible condition and it requires the immediate attention of the Government to remediate the problem. The surveys carried out by Road Research Department of Nigerian Building and Road Research Institute and below were the observations.

Table 2 summarizes the evaluation of the bridges and recommendations by the team of engineers in accordance to the SECR. 
Table 2: Structural Element Condition Ratings (SECR)

\begin{tabular}{|c|c|c|c|c|c|c|}
\hline Variable List & Uke Bridge & $\begin{array}{l}\text { Hadari } \\
\text { Bridge }\end{array}$ & $\begin{array}{c}\text { GwanjeDud } \\
\text { i Bridge }\end{array}$ & $\begin{array}{l}\text { Dindima } \\
\text { Bridge }\end{array}$ & $\begin{array}{c}\text { Gwaram } \\
\text { Bridge }\end{array}$ & $\begin{array}{l}\text { Kwadon/Liji/ } \\
\text { Kurba Bridge }\end{array}$ \\
\hline $\begin{array}{l}\text { Bituminous } \\
\text { Approach } \\
\text { Roadway }\end{array}$ & $\begin{array}{l}\text { Significant } \\
\text { rutting, } \\
\text { extensive } \\
\text { cracking } \\
\text { SECR: } 3\end{array}$ & $\begin{array}{l}\text { Smooth } \\
\text { and even } \\
\text { (no } \\
\text { potholes) } \\
\text { SECR: } 1\end{array}$ & $\begin{array}{c}\text { Moderate } \\
\text { cracking or } \\
\text { slight rutting } \\
\text { SECR: } 2\end{array}$ & $\begin{array}{c}\text { Severe } \\
\text { deteriorati } \\
\text { on } \\
\\
\text { SECR: } 4\end{array}$ & $\begin{array}{l}\text { Moderate } \\
\text { cracking or } \\
\text { slight } \\
\text { rutting } \\
\text { SECR: } 2\end{array}$ & $\begin{array}{c}\text { Severe } \\
\text { deterioration } \\
\text { (possible } \\
\text { traffic hazard) } \\
\text { SECR: } 4\end{array}$ \\
\hline Wearing Course & $\begin{array}{c}\text { Minor } \\
\text { deterioration } \\
\text { SECR: } 2\end{array}$ & $\begin{array}{l}\text { Significant } \\
\text { wearing or } \\
\text { rutting } \\
\text { SECR: } 3\end{array}$ & $\begin{array}{c}\text { No potholes, } \\
\text { minor } \\
\text { wearing }\end{array}$ & $\begin{array}{l}\text { No } \\
\text { potholes, } \\
\text { moderate } \\
\text { wearing } \\
\text { SECR: } 2\end{array}$ & $\begin{array}{c}\text { No } \\
\text { potholes, } \\
\text { minor } \\
\text { wearing } \\
\text { SECR: } 1\end{array}$ & $\begin{array}{l}\text { No potholes, } \\
\text { no patches or } \\
\text { repairs. } \\
\text { No cracks } \\
\text { SECR: } 1\end{array}$ \\
\hline $\begin{array}{c}\text { Deck Expansion } \\
\text { Joints }\end{array}$ & $\begin{array}{l}\text { Some finger } \\
\text { joint plates } \\
\text { missing, } \\
\text { joint is } \\
\text { completely } \\
\text { restricted } \\
\text { (no longer } \\
\text { functioning) } \\
\text { SECR: } 4\end{array}$ & $\begin{array}{c}\text { Severe } \\
\text { traffic } \\
\text { damage, } \\
\text { prevents } \\
\text { proper } \\
\text { joint } \\
\text { function, } \\
\text { presents a } \\
\text { safety } \\
\text { hazard } \\
\text { SECR: } 4\end{array}$ & $\begin{array}{l}\text { Moderate } \\
\text { spalling that } \\
\text { does not } \\
\text { affect joint } \\
\text { function } \\
\text { Bituminous } \\
\text { patching } \\
\text { observed } \\
\text { SECR: } 2\end{array}$ & $\begin{array}{l}\text { Joint is } \\
\text { completely } \\
\text { restricted } \\
\text { by debris } \\
\text { (not } \\
\text { functionin } \\
\text { g) } \\
\text { SECR: } 4\end{array}$ & $\begin{array}{c}\text { Horizontal } \\
\text { joint gap is } \\
\text { within } \\
\text { design } \\
\text { limits }\end{array}$ & $\begin{array}{l}\text { Joint is closed } \\
\text { tightly, design } \\
\text { didn't allow } \\
\text { proper girder } \\
\text { expansion } \\
\text { (Structural } \\
\text { review is } \\
\text { required) } \\
\text { SECR:4 }\end{array}$ \\
\hline $\begin{array}{c}\text { Steel/Reinforced } \\
\text { Concrete } \\
\text { Railings }\end{array}$ & $\begin{array}{l}\text { Leaching } \\
\text { without } \\
\text { build-up or } \\
\text { rust staining }\end{array}$ & $\begin{array}{l}\text { Spalling } \\
\text { deeper } \\
\text { than 4" or } \\
\text { exposed } \\
\text { rebar with } \\
\text { severe } \\
\text { section } \\
\text { loss } \\
\text { SECR: } 3 \\
\end{array}$ & $\begin{array}{l}\text { Steel railings } \\
\text { severely torn } \\
\text { or missing. } \\
\text { Leaching } \\
\text { without } \\
\text { build-up or } \\
\text { rust staining } \\
\text { of RC } \\
\text { SECR: } 3\end{array}$ & $\begin{array}{l}\text { Numerous } \\
\text { steel } \\
\text { railings } \\
\text { missing } \\
\text { (possible } \\
\text { traffic } \\
\text { hazard) }\end{array}$ & $\begin{array}{l}\text { Aluminum } \\
\text { railings } \\
\text { severely } \\
\text { bent, torn } \\
\text { or missing } \\
\text { (possible } \\
\text { traffic } \\
\text { hazard) } \\
\text { SECR: } 4\end{array}$ & $\begin{array}{l}\text { Aluminum } \\
\text { railings } \\
\text { severely bent, } \\
\text { torn or } \\
\text { missing } \\
\text { (possible } \\
\text { traffic hazard) } \\
\text { SECR: } 4\end{array}$ \\
\hline $\begin{array}{c}\text { Deck \& } \\
\text { Approach } \\
\text { Drainage }\end{array}$ & $\begin{array}{c}\text { Drainage } \\
\text { system is not } \\
\text { functioning } \\
\text { properly. } \\
\text { Drainage } \\
\text { system is } \\
\text { clogged with } \\
\text { debris } \backslash \\
\text { SECR: } 3\end{array}$ & $\begin{array}{l}\text { Drainage } \\
\text { system is } \\
\text { clogged } \\
\text { with debris } \\
\text { and } \\
\text { deteriorati } \\
\text { ng girders } \\
\text { underneath } \\
\text { SECR: } 3\end{array}$ & $\begin{array}{l}\text { Drainage } \\
\text { system is not } \\
\text { functioning } \\
\text { properly. } \\
\text { Drainage } \\
\text { system is } \\
\text { clogged with } \\
\text { debris } \\
\text { SECR: } 3\end{array}$ & $\begin{array}{c}\text { Drainage } \\
\text { system is } \\
\text { not } \\
\text { functionin } \\
\text { g properly. } \\
\text { Drainage } \\
\text { system is } \\
\text { clogged } \\
\text { with debris } \\
\text { SECR: } 3\end{array}$ & $\begin{array}{c}\text { Drainage } \\
\text { system is } \\
\text { not } \\
\text { functionin } \\
\text { g properly. } \\
\text { Drainage } \\
\text { system is } \\
\text { clogged } \\
\text { with debris } \\
\text { SECR: } 3\end{array}$ & $\begin{array}{l}\text { Nil } \\
\text { (Structural } \\
\text { review is } \\
\text { required) }\end{array}$ \\
\hline $\begin{array}{c}\text { Deck Bottom } \\
\text { Surface and } \\
\text { Vertical Fascia }\end{array}$ & $\begin{array}{c}\text { Light } \\
\text { leaching } \\
\text { (little or no } \\
\text { buildup). } \\
\text { Water } \\
\text { saturation } \\
\text { SECR: } 2\end{array}$ & $\begin{array}{c}\text { Heavy } \\
\text { leaching } \\
\text { (significant } \\
\text { build-up or } \\
\text { stalactites) } \\
\text { SECR: } 2\end{array}$ & $\begin{array}{l}\text { Tree growth } \\
\text { on fascia, } \\
\text { water } \\
\text { saturation } \\
\text { SECR:4 }\end{array}$ & $\begin{array}{l}\text { Irrelevant } \\
\text { leaching } \\
\text { on fascia } \\
\text { and deck } \\
\text { bottom } \\
\text { surface } \\
\text { SECR: } 1\end{array}$ & $\begin{array}{l}\text { Irrelevant } \\
\text { leaching } \\
\text { on fascia } \\
\text { and deck } \\
\text { bottom } \\
\text { surface } \\
\text { SECR: } 1\end{array}$ & $\begin{array}{c}\text { Light leaching } \\
\text { (little or no } \\
\text { buildup), } \\
\text { Water } \\
\text { saturation } \\
\text { SECR: } 2\end{array}$ \\
\hline
\end{tabular}




\begin{tabular}{|c|c|c|c|c|c|c|}
\hline Variable List & Uke Bridge & $\begin{array}{l}\text { Hadari } \\
\text { Bridge }\end{array}$ & $\begin{array}{c}\text { GwanjeDud } \\
\text { i Bridge } \\
\end{array}$ & $\begin{array}{l}\text { Dindima } \\
\text { Bridge }\end{array}$ & $\begin{array}{c}\text { Gwaram } \\
\text { Bridge }\end{array}$ & $\begin{array}{l}\text { Kwadon/Liji/ } \\
\text { Kurba Bridge }\end{array}$ \\
\hline $\begin{array}{c}\text { Reinforced } \\
\text { Concrete } \\
\text { Girders }\end{array}$ & $\begin{array}{c}\text { No repairs } \\
\text { are present, } \\
\text { no } \\
\text { delamination } \\
\text { observed } \\
\text { SECR: } 1\end{array}$ & $\begin{array}{l}\text { Leaching } \\
\text { without } \\
\text { build-up } \\
\text { (stalactites } \\
\text { ) or rust } \\
\text { staining } \\
\text { SECR: } 2\end{array}$ & $\begin{array}{l}\text { Leaching } \\
\text { without } \\
\text { build-up } \\
\text { (stalactites) } \\
\text { or rust } \\
\text { staining } \\
\text { SECR: } 2\end{array}$ & Nil & Nil & Nil \\
\hline Steel Girders & Nil & Nil & Nil & $\begin{array}{l}\text { Connectio } \\
\mathrm{n} \text { in-place } \\
\text { and } \\
\text { functionin } \\
\mathrm{g} \text { as } \\
\text { intended } \\
\text { SECR: } 1\end{array}$ & $\begin{array}{c}\text { Corrosion } \\
\text { beyond the } \\
\text { initial layer } \\
\text { of } \\
\text { protective } \\
\text { oxide } \\
\text { coating } \\
\text { SECR: } 2\end{array}$ & $\begin{array}{c}\text { Flaking rust } \\
\text { (and pitting) } \\
\text { in girder web } \\
\text { at splice } \\
\text { SECR: } 3\end{array}$ \\
\hline Bearings & $\begin{array}{l}\text { Elastomeric } \\
\text { bearings are } \\
\text { properly } \\
\text { positioned } \\
\text { and } \\
\text { functioning } \\
\text { well } \\
\\
\text { SECR: } 1\end{array}$ & $\begin{array}{l}\text { Elastomeri } \\
\text { c bearing } \\
\text { is } \\
\text { restricted } \\
\text { but not } \\
\text { warranting } \\
\text { structural } \\
\text { review } \\
\text { SECR: } 2\end{array}$ & $\begin{array}{l}\text { Freckled rust } \\
\text { (corrosion } \\
\text { has initiated, } \\
\text { no repairs } \\
\text { required) } \\
\text { SECR: } 2\end{array}$ & $\begin{array}{l}\text { Disk } \\
\text { bearing } \\
\text { needs } \\
\text { resetting, } \\
\text { repairs, or } \\
\text { bearing } \\
\text { replaceme } \\
\text { nt are } \\
\text { required } \\
\text { SECR: } 4\end{array}$ & $\begin{array}{l}\text { Minor } \\
\text { Disk } \\
\text { bearing } \\
\text { restriction, } \\
\text { cleaning } \\
\text { recommen } \\
\text { ded } \\
\text { SECR: } 2\end{array}$ & $\begin{array}{l}\text { Fixed concrete } \\
\text { bearings not } \\
\text { allowing for } \\
\text { any movement } \\
\text { (structural } \\
\text { review is } \\
\text { warranted) } \\
\text { SECR: } 4\end{array}$ \\
\hline $\begin{array}{c}\text { Reinforced } \\
\text { Concrete Piers }\end{array}$ & $\begin{array}{l}\text { Spall deeper } \\
\text { than 1" or } \\
\text { greater than } \\
6 \text { " in } \\
\text { diameter. } \\
\text { Exposed } \\
\text { rebar with } \\
\text { section loss } \\
\text { SECR: } 3\end{array}$ & $\begin{array}{c}\text { Coarse } \\
\text { aggregate } \\
\text { is exposed } \\
\text { but } \\
\text { remains } \\
\text { secure } \\
\\
\text { SECR: } 2\end{array}$ & $\begin{array}{l}\text { Leaching } \\
\text { without } \\
\text { build-up or } \\
\text { rust staining, } \\
\text { Moderate } \\
\text { width cracks } \\
\text { SECR: } 2\end{array}$ & $\begin{array}{c}\text { Moderate } \\
\text { map } \\
\text { cracking, } \\
\text { Coarse } \\
\text { aggregate } \\
\text { is exposed } \\
\text { but } \\
\text { remains } \\
\text { secure } \\
\text { SECR: } 2\end{array}$ & Nil & Nil \\
\hline $\begin{array}{c}\text { Reinforced } \\
\text { Concrete Pier } \\
\text { Walls }\end{array}$ & Nil & Nil & Nil & Nil & $\begin{array}{l}\text { Leaching } \\
\text { without } \\
\text { build-up or } \\
\text { rust } \\
\text { staining } \\
\text { SECR: } 2 \\
\end{array}$ & Nil \\
\hline $\begin{array}{c}\text { Reinforced } \\
\text { Concrete Pier } \\
\text { Caps }\end{array}$ & $\begin{array}{l}\text { Leaching } \\
\text { without } \\
\text { build-up or } \\
\text { rust staining } \\
\text { SECR: } 2\end{array}$ & $\begin{array}{l}\text { Moderate } \\
\text { map } \\
\text { cracking, } \\
\text { Leaching } \\
\text { without } \\
\text { build-up or } \\
\text { rust } \\
\text { staining } \\
\text { SECR: } 2\end{array}$ & $\begin{array}{c}\text { Leaching } \\
\text { without } \\
\text { build-up or } \\
\text { rust staining }\end{array}$ & $\begin{array}{l}\text { Structural } \\
\text { review is } \\
\text { not } \\
\text { required, } \\
\text { no repairs } \\
\text { are } \\
\text { required } \\
\text { SECR: } 1\end{array}$ & Nil & Nil \\
\hline
\end{tabular}




\begin{tabular}{|c|c|c|c|c|c|c|}
\hline Variable List & Uke Bridge & $\begin{array}{l}\text { Hadari } \\
\text { Bridge }\end{array}$ & $\begin{array}{c}\text { GwanjeDud } \\
\text { i Bridge } \\
\end{array}$ & $\begin{array}{c}\text { Dindima } \\
\text { Bridge }\end{array}$ & $\begin{array}{c}\text { Gwaram } \\
\text { Bridge }\end{array}$ & $\begin{array}{l}\text { Kwadon/Liji/ } \\
\text { Kurba Bridge }\end{array}$ \\
\hline $\begin{array}{c}\text { Reinforced } \\
\text { Concrete Pile } \\
\text { Caps/Footing }\end{array}$ & $\begin{array}{l}\text { Spall deeper } \\
\text { than 1" or } \\
\text { greater than } \\
6 \text { " in } \\
\text { diameter. } \\
\text { Exposed } \\
\text { rebar with } \\
\text { section loss } \\
\text { SECR: } 3\end{array}$ & $\begin{array}{l}\text { Scour } \\
\text { exceeds } \\
\text { tolerable } \\
\text { limits but } \\
\text { less than } \\
\text { critical } \\
\text { scour } \\
\text { limits } \\
\text { SECR: } 3\end{array}$ & $\begin{array}{l}\text { Scour within } \\
\text { tolerable } \\
\text { limits, } \\
\text { Some caps } \\
\text { exposed } \\
\\
\text { SECR: } 2\end{array}$ & $\begin{array}{c}\text { Course } \\
\text { aggregate } \\
\text { is exposed } \\
\text { but } \\
\text { remains } \\
\text { secure, } \\
\text { Scour } \\
\text { within } \\
\text { tolerable } \\
\text { limit } \\
\text { SECR: } 2\end{array}$ & $\begin{array}{l}\text { Moderate } \\
\text { map } \\
\text { cracking, } \\
\text { Scour } \\
\text { exceeds } \\
\text { tolerable } \\
\text { limits but } \\
\text { less than } \\
\text { critical } \\
\text { scour } \\
\text { limits } \\
\text { SECR: } 3 \\
\end{array}$ & Nil \\
\hline $\begin{array}{c}\text { Reinforced } \\
\text { Concrete } \\
\text { Abutments }\end{array}$ & $\begin{array}{l}\text { Moderate } \\
\text { map } \\
\text { cracking, } \\
\text { Course } \\
\text { aggregate is } \\
\text { exposed but } \\
\text { remains } \\
\text { secure } \\
\text { SECR: } 2\end{array}$ & $\begin{array}{c}\text { Tree } \\
\text { growth on } \\
\text { bearing } \\
\text { seat, Wide } \\
\text { cracks or } \\
\text { heavy } \\
\text { pattern } \\
\text { (map) } \\
\text { cracking } \\
\text { SECR: } 3\end{array}$ & $\begin{array}{l}\text { Moderate } \\
\text { map } \\
\text { cracking, } \\
\text { Scour is } \\
\text { within } \\
\text { tolerable } \\
\text { limits } \\
\text { SECR: } 2\end{array}$ & $\begin{array}{l}\text { Condition } \\
\text { warrants } \\
\text { structural } \\
\text { review, } \\
\text { Stability of } \\
\text { element } \\
\text { has been } \\
\text { reduced } \\
\text { SECR: } 4\end{array}$ & $\begin{array}{l}\text { No scour, } \\
\text { moderate } \\
\text { map } \\
\text { cracking. } \\
\text { Leaching } \\
\text { without } \\
\text { build-up or } \\
\text { rust } \\
\text { staining } \\
\text { SECR: } 2\end{array}$ & $\begin{array}{c}\text { Severe } \\
\text { structural } \\
\text { cracking, } \\
\text { Condition } \\
\text { warrants } \\
\text { structural } \\
\text { review } \\
\text { SECR: } 4\end{array}$ \\
\hline $\begin{array}{l}\text { Slope And Slope } \\
\text { Protection }\end{array}$ & $\begin{array}{l}\text { Minor to } \\
\text { moderate } \\
\text { deterioration } \\
\text { or loss of } \\
\text { protection } \\
\text { (slight } \\
\text { undermining } \\
\text { ) } \\
\text { SECR: } 2\end{array}$ & $\begin{array}{c}\text { Severe } \\
\text { deteriorati } \\
\text { on, loss of } \\
\text { protection, } \\
\text { or } \\
\text { undermini } \\
\text { ng. } \\
\text { Significant } \\
\text { loss of } \\
\text { abutment } \\
\text { backfill } \\
\text { SECR: } 3\end{array}$ & $\begin{array}{c}\text { Significant } \\
\text { deterioration } \\
\text { or loss of } \\
\text { protection } \\
\text { (significant } \\
\text { undermining } \\
\text { ), growth of } \\
\text { trees on } \\
\text { slope } \\
\text { SECR: } 3\end{array}$ & $\begin{array}{l}\text { Minor to } \\
\text { moderate } \\
\text { deteriorati } \\
\text { on of } \\
\text { protection, } \\
\text { Moderate } \\
\text { loss of } \\
\text { approach } \\
\text { backfill } \\
\text { SECR: } 3\end{array}$ & $\begin{array}{l}\text { Minor to } \\
\text { moderate } \\
\text { deteriorati } \\
\text { on or loss } \\
\text { of } \\
\text { protection } \\
\text { (slight } \\
\text { undermini } \\
\text { ng) } \\
\text { SECR: } 2\end{array}$ & $\begin{array}{c}\text { Severe } \\
\text { deterioration } \\
\text { and erosion, } \\
\text { Significant } \\
\text { loss of } \\
\text { abutment or } \\
\text { approach } \\
\text { backfill } \\
\text { SECR: } 4\end{array}$ \\
\hline
\end{tabular}

It should be noted that ratings 1 and 2 require no immediate attention while ratings 3 and 4 require maintenance and immediate maintenance/replacement respectively.

The rehabilitation/maintenance/replacement measures to retain or improve safety and serviceability conditions on the girder bridges include:

1. There is need for replacement of numerous expansion joints and resurfacing of the wearing course around the joints.

2. Re-fill and compaction of backfill, rehabilitation of stone pitching on the embankments that have eroded and the application of any slope stabilization technique where it is needed but absent.

3. Installation of gabion baskets to protect and support exposed piles.

4. General repair of concrete members that have undergone extreme cracking/spalling or section loss and have exposed rebar. This requires the removal of loose concrete and aggregate, cleaning of the concrete surface and rebar, then use of epoxy to bond new concrete to the existing concrete surface. Fibrereinforced plastic (FRP) may also be used to increase strength and durability of the repaired section.

5. General sanitation of the girder bridges; removal of silt, refuse and debris from bridge components and bridge premises.

6. Removal and clearance of unwanted vegetation and trees from bridge decks, fascia, pier caps, abutment seats and embankments.

7. De-silting of drain pipes and installation of drain filters and seals where necessary.

8. Re-installation of missing railings.

9. Removal of decaying formwork still in place under the soffit and of the sides of the girders of the Gwanje Bridge. 
10. Reconstruction of the failing bituminous roadway approach from Bauchi for the Dindima Bridge.

11. Repair, resetting or replacement of ageing or faulty bearings where necessary.

12. Repainting of the steel girders for the composite girder bridges to increase protection against weathering effects.

13. Lastly, for the Kwadon / Liji /Kurba Bridge, it needs to be reconstructed as it has failed and has been sealed off to general traffic due to safety concerns. It is advised that a reputable construction company is awarded the contract.

\section{REFERENCES}

1. Agbakwuru, J.(2018, August 9). FEC approves N348.5bn for Akwanga-Gombe road. Vanguard. Retrieved from https://www.vanguardngr.com

2. Al-Baijat, H., Alhawamdeh, M. (2019) Inspection and Assessment of Highway Bridges in Jordan along the Desert Highway: A Case Study. Open Journal of Composite Materials , 9, 249-259. https://doi.org/10.4236/ojcm.2019.93014

3. American Association of State Highway and Transportation Officials Special Report. (2016). Survey Finds a Growing Number of State DOTS are Using Drones to Improve Safety and Collect Data Faster and BetterSaving Time and Money.

4. Barritt, L. (2018) Improving the Quality of Bridge Inspections Using Unmanned Aircraft Systems (UAS). Research Project. Collins Engineers, Inc., Department of Transportation Minnesota.

5. Bharil, R.K. (2016). Innovative Bridge Design Handbook. Construction, Rehabilitation and Maintenance. P. pp 359-380. https://doi.org/10.1016/B978-0-12-800058-8.00014-1

6. Bridge Masters. (2017). Approaching Bridge Maintenance More Efficiently, Bridge work, Bridges and Utilities.

7. Duque, L. (2017). UAV-Based Bridge Inspection and Computational Simulations. Theses and Dissertations. 2159. https://openprairie.sdstate.edu/etd/2159

8. Ehsani, M., Croarkin, M. (2010). A Novel Solution for Restoration of Deteriorated Piles. Missouri DOT pioneers the implementation of the next generation of FRP products.

9. Gillins, M.N. (2011). Unmanned Aircraft Systems for Bridge Inspection: Testing and Developing End-ToEnd Operational Workflow. Thesis. P. pp 6-11.

10. Graybeal, B.A, Washer, G. (2001). Reliability of Visual Inspection for Highway Bridges, Technical Report. https://www.researchgate.net/publication/273680040

11. Hüthwohl, P., Lu, R., Brilakis, I. (2016). Challenges of Bridge Maintenance Inspection. Conference Paper. https://www.researchgate.net/publication/305303241

12. Lamb, R., Morrissey, M. (2000). How Bridges Work. HowStuffWorks.com. https://science.howstuffworks.com/engineering/civil/bridge.html

13. Michigan Department of Transportation. (2009). Pontis Bridge Inspection Manual.

14. Minnesota Department of Transportation. (2016). Bridge Inspection Field Manual Version 2.0.

15. REDNOA Inc. (2017). A Report on The use of Unmanned Aerial Systems (UAS) to Remotely Collect Data for Road Infrastructure. P. pp 12-15.

16. Wapwera, S.D., Ayanbimpe, G.M. and Odita, C.E. (2015). Abandoned Mine, Potential Home for the People: A Case Study of Jos Plateau Tin-Mining Region. Journal of Civil Engineering and Architecture 9 (2015) 429445. doi: 10.17265/1934-7359/2015.04.007 